\title{
Short Communication: Rediscovery of Psychotria species, subspecies, and varieties collected in the 1990s and new records of Antirhea benguetensis (Elmer) Valeton and Ixora longifolia Smith (Rubiaceae) in Northern Sierra Madre Natural Park, Luzon, Philippines
}

\author{
RACHEL D. BIAG ${ }^{1,2, \boldsymbol{v}}$, GRECEBIO JONATHAN D. ALEJANDRO ${ }^{1,3}$ \\ ${ }^{1}$ The Graduate School and Research Centre for the Natural and Applied Sciences, University of Santo Tomas. España Blvd., 1015 Manila, Philippines \\ ${ }^{2}$ Department of Natural Sciences, College of Arts and Sciences, Cagayan State University. Carig Campus, Tuguegarao City, Cagayan, Philippines \\ ${ }^{3}$ Department of the Biological Sciences, College of Science, University of Santo Tomas. España Boulevard, 1015 Manila, Philippines \\ •email: biagrachel27ust@gmail.com/rachel.biag@yahoo.com
}

Manuscript received: 11 July 2020. Revision accepted: 29 September 2020.

\begin{abstract}
Biag RD, Alejandro GJD. 2020. Short Communication: Rediscovery of Psychotria species, subspecies and varieties collected in the 1990s and new records of Antirhea benguetensis (Elmer) Valeton and Ixora longifolia Smith (Rubiaceae) in Northern Sierra Madre Natural Park, Luzon, Philippines. Biodiversitas 21: 4524-4535. Tagged as the "last great forest" for it possesses the widest remaining tropical rainforest in the island of Luzon, the Northern Sierra Madre Natural Park (NSMNP) in the province of Isabela is worth-conserving. Owing to the species richness and high levels of endemism in the said area, it was identified as a key biodiversity area for conservation and protection. After a botanical exploration in the park conducted from April to August 2019, 89 Rubiaceae species were found dominated by the genus Psychotria. These Psychotria species were then separated from other genera and were morphologically examined and eventually identified. This study, therefore, primarily aims to provide the list of Psychotria species that were collected long before, particularly in the 1990s and still exist in NSMNP continuously battling against the catastrophic activities within the forest. Eight Philippine endemic Psychotria species and varieties were recollected. As to their current conservation status following IUCN criteria, we herein propose these species, except for Psychotria pubilimba, to be treated as Data Deficient (DD) since there is lack of distributional data for these species. Additional surveys are to be conducted on the areas where these species were previously collected. In this way, information on population size and threats to the species can also be obtained. $P$. pubilimba is restricted to Cagayan and Isabela. Only one mature individual has been found; hence, a Narrow Endemic Species (NES). Being an NES, it was then assessed as Critically Endangered (CR) based on IUCN rules. It is also worth noting that new records of Antirhea benguetensis and Ixora longifolia species were found in the park, particularly in Divilacan, Isabela. The former has been regarded as Luzon endemic, known to be distributed only in Benguet, Ilocos Sur, Rizal, and Bataan. The latter, on the other hand, is mostly distributed in the provinces of Visayas and Mindanao, and only Masbate and Palawan for Luzon. Moreover, this flora has been recorded in other parts of the world like China, India, Myanmar, Indonesia, Malaysia, and Vietnam.
\end{abstract}

Keywords: New records, Northern Sierra Madre Natural Park, Psychotria, rediscovery

\section{INTRODUCTION}

Psychotria L. (Rubiaceae, Rubioideae, Psychotrieae) is a pantropical genus with 3,400 accepted names in the Plants of the World Online (POWO) (2020). It is the most speciose of the coffee family and the $3^{\text {rd }}$ largest of all the angiosperms (Davis et al. 2001, 2009; Razafimandimbison 2014). They form the understorey of tropical and subtropical forests as small trees, shrubs, herbs, suffrutescents, and rarely as lianas and epiphytes (Alejandro and Liede 2003; Virillo et al. 2007; Taylor 2016). This genus is recognizable by the following characters: caducous stipule, terminal inflorescences, small corolla, stamens (i.e., filaments) inserted within the ring of corolla throat hairs, pyrenes usually with ribs or ridges on the outer surface and two marginal preformed slits, also in the seed coat with a red pigment that is soluble in $70 \%$ ethanol; and ruminate endosperm (Sohmer and Davis 2007;
Chen et al. 2011; Barrabé et al. 2012; Razafimandimbison 2014; Taylor 2016). The Philippine Psychotria species can be divided into nine groups providing a practical means for subdividing Psychotria into more manageable units (Sohmer and Davis 2007). As a result, any single species can be placed into a smaller group of species and then more easily identified to species, subspecies, or variety. In the Philippines, 112 species (Sohmer and Davis 2007; Tan et al. 2014) of Psychotria are present, and 106 are endemic to the country as recorded in the Co's Digital Flora of the Philippines by Pelser et al. (2011). Through the Philippine Plant Inventory (PPI) project conducted between 1990 and 1997, 43 species out of the 112 species of Philippine Psychotria were recollected (Sohmer and Davis 2007). After conducting a series of field works, 89 Rubiaceae species were collected and dominated by Psychotria. It is in this premise that we decided to reinvestigate this genus, especially that recollection of its species was done in the 1990s. 
The surveyed site is one of the 17 critical conservation priority areas in the country identified by the United Nations Educational, Scientific and Cultural Organization (UNESCO) and the Department of Environment and Natural Resources (DENR) and one of the country's ten priority protected areas, the Northern Sierra Madre Natural Park (NSMNP) (van der Ploeg et al. 2011). It was tagged as "the last great forest" because it is the widest remaining tropical rainforest on the island of Luzon (DENR 2017; Mabuwaya Foundation 2018). Also, it is a known area where numerous Psychotria species are found (Sohmer and Davis 2007). However, like any other forests, NSMNP is not being spared from anthropogenic influences resulting in its destruction and directly impacting the biodiversity of both flora and fauna (van der Ploeg et al. 2011). Davis and Sohmer (2004) mentioned that many of these Philippine floras are now presumed to be extinct. Psychotria, for instance, is among those plants whose outlook for survival is almost catastrophic. Davis's estimate of extinction for Philippine Psychotria, which is mainly due to rapid habitat losses, is $30 \%$ and that $50 \%$ given by Sohmer (2001) is comparable with the $24 \%$ and $56 \%$ range for the extinction of Philippine flora given by Koopowitz et al. (1998). This crisis faced by Psychotria was even compounded with the idea that a significant number of the taxa have not been recollected since that era of Philippine botany ended in the late 1920s.

Botanical records revealed that both Antirhea benguetensis (Elmer) Valeton and Ixora longifolia Smith are not floras of the national park (Guingab and van Welzen 2018). However, our study proves their existence, hence are new records in the area. The former was originally named as Guettardella microphylla (DC.) M.E. Jansen but was given a new name, Antirhea benguetensis (Elmer) Valeton, due to the revisions in Philippine Rubiaceae species (Alejandro and Liede 2003).

In the current study, it highlights the importance of recollecting Psychotria species to provide perspective as to its conservation status, an update on its geographical distributions as well as the provision of taxonomical notes for each species. It also emphasizes the discovery of new records of Antirhea benguetensis (Elmer) Valeton and Ixora longifolia Smith in the area due to the conduct of floristic surveys.

\section{MATERIALS AND METHODS}

\section{Study area}

Fieldwork was done in one of the most important protected areas in Luzon, Philippines, the Northern Sierra Madre Natural Park (NSMNP). It is located in the eastern mid part of Isabela Province at geographical grids between $15^{\circ} 59^{\prime} 35^{\prime \prime}$ to $18^{\circ} 3^{\prime} 11^{\prime \prime} \mathrm{N}$ and $121^{\circ} 17^{\prime} 35^{\prime \prime}$ to $122^{\circ} 33^{\prime} 29^{\prime \prime}$ E (Figure 1). The Park has a total area of 359,486 ha corresponding geographically with the four eastern coastal municipalities of 1. Palanan, 2. Divilacan, 3. Maconacon and 4. Dinapigue, and portions of 5. San Mariano, 6. San Pablo, 7. Cabagan, 8. Tumauini and 9. Ilagan at the western slopes of Sierra Madre. River, on the west by the Cagayan Valley, and the east by the Pacific Ocean. Its elevation ranges from 200 to 1,844 meters above sea level and a slope which is steep to very steep. Also, NSMNP is known for its undifferentiated mountain soils, which is about $96.73 \%$ of the entire Park area, with outcrops of rock formation in the mountainous sections and patches of alluvial deposits along the valleys. The north-western part of NSMNP has a type III climate that is greatly affected by the southwest monsoon. The type IV of climate, characterized by no pronounced maximum rain period and no dry season, covers the eastern part of the park. Aside from climatic conditions, a mosaic of habitat types present in NSMNP (lowland dipterocarp forests, lower montane, and mossy forests, limestone forests, ultrabasic forests, beach forests, wetlands, mangrove, seagrass and reefs ecosystems) greatly influenced the area's biological diversity (DENR, 2017).

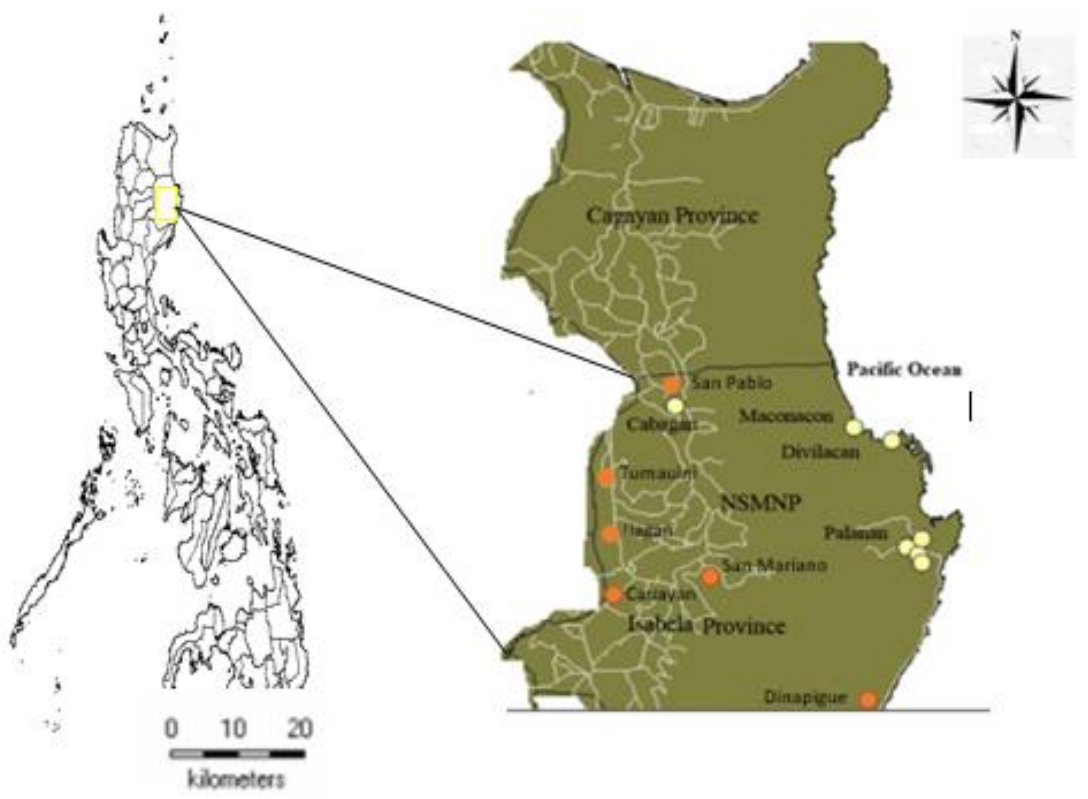

Figure 1. Map of the Philippines showing the Isabela Province where Northern Sierra Madre Natural Park (NSMNP) is located. Areas surveyed are marked in cream circles — map generated by DIV AJIS 7.5.0 


\section{The sampling, collection, and morphological} examinations of specimens

This botanical study was conducted in four field expeditions from April to August 2019. Purposive sampling was employed in the study. The collection was done along and approximately $10 \mathrm{~m}$ adjacent to trails at the study sites (Ordas et al. 2019). All plants having the characters of Rubiaceae were collected during their reproductive stages to ensure precise identification of species. Specimens initially identified as Psychotria were separated from other genera. Voucher specimens were then deposited in the University of Santo Tomas Herbarium (USTH). Comprehensive morphological examinations of both vegetative and reproductive parts of each Psychotria were carried out using a foldable magnifier and cordless Prepscope compound microscope. A vernier caliper was utilized whenever the measurement of a part is required. These examinations led to the comparison of the noted characters with those written in the Sohmer and Davis (2007). Character states presented for each species were based on Beentje (2016). For the Rubiaceae species newly recorded in the national park, the same morphological examinations utilized to investigate Psychotria were done to provide a taxonomic description of the species.

\section{Identification of plant materials}

For easier identification, herbarium specimens from local herbaria such as the Philippine National Museum (PNH), University of the Philippines Los Banos-Museum of Natural History (CAHUP), University of Santo TomasHerbarium (USTH), and Environmental Information Center Herbarium-Isabela State University, Cabagan (EICHISUC) were observed. A comparison of our materials with those good quality images in the "Co's Digital Flora of the Philippines" (Pelser et al. 2011) was also made. Type specimens from local as well as databases of foreign herbaria such as Smithsonian Institution (US), the Leiden Herbarium (L), Royal Botanic Gardens Kew (K), The Natural History Museum in London (BM), Gray Herbarium-Harvard University (GH), New York Botanical Garden (NY), Herbarium of Bernice P. Bishop Museum (BISH), and Arnold Arboretum-Harvard University Herbarium (A), accessed from Global Biodiversity Information Facility (GBIF) (1999) were also utilized. With these, the identity of the species was known. The conservation status of species was determined using the IUCN criteria. Consultation to the World Checklist of Rubiaceae Govaerts (2011), International Plant Names Index (IPNI) (2020), and Plants of the World Online (POWO) (2020) was done to provide the correct scientific name for each species. DIVA-GIS v. 7.5.0 was used for the preparation of the map.

\section{RESULTS AND DISCUSSION}

Of the 89 species of Rubiaceae collected, five species, one subspecies, and two varieties of Pychotria were rediscovered after a series of fieldwork conducted in NSMNP. Each was taxonomically described based on its morphological characters, distribution, habitat, phenology, year of the last collection, vernacular name, specimens examined and conservation status based on IUCN. Taxonomical notes and associated species were also provided for each of the species. Figures 2 and 3 reveal the photos of the different species of Psychotria. Two new records of Rubiaceae Antirhea benguetensis (Elmer) Valeton and Ixora longifolia Smith (Figs. 4 and 5) were also discovered and were assessed as new records in the park. Only one species of Antirhea was collected, while for Ixora, three species were found during the survey. These are Ixora salicifolia (Blume) De Candolle and Ixora leucocarpa Elmer in addition to the Ixora longifolia.

\section{Taxonomy of the rediscovered Psychotria species, subspecies, and varieties}

Psychotria gitingensis Elmer, Leafl. Philipp. Bot. 3: 1025. 1911.

TYPE: Philippines. Sibuyan: Romblon Prov.: Mt. Giting-giting, May 1910, Elmer 12439 (lectotype, designated by S. H. Sohmer [1985], GH [barcode] 00095527 digital image!, isolectotypes, A [barcode] 00095528 digital image!, K [barcode] 000777275 digital image!).

Description: Small tree, $5 \mathrm{~m}$ tall. Stipules valvate, ovate-triangular, $0.8 \mathrm{~cm}$ long. Leaves: petioles $0.6-1.5 \mathrm{~cm}$ long, leaf blades lanceolate, $8-14 \times 2.4-4.0 \mathrm{~cm}$, coriaceous, greenish-brown when dry, glabrous above and below; secondary veins $10-14$ pairs; tertiary venation weak to obscure; base acute; apex acute. Infructescences monochotomous, $9.4 \mathrm{~cm}$ long. Fruits subobovoid to turbinate, 6-8 mm long, ribbed, yellow; calyx limb and lobes absent; pyrene ribbed on outer surface; endosperm ruminate.

Distribution: Endemic to the Philippines, and it is widely distributed in Luzon, Visayas, and Mindanao (Sohmer and Davis 2007).

Habitat: Lowland dipterocarp rainforest at an elevation of $63 \mathrm{~m}$ asl.

Phenology: Observed fruiting in July.

Year last collected: 1996

Vernacular name: Merritt-katagpo.

Conservation status: Based on IUCN criteria, Sohmer's preliminary assessment in 2007 of this species is Least Concern (LC), as this is widely distributed in the Philippine archipelago. Only one (Divilacan) out of the four study sites harbors this flora, and 20 individuals were observed. Given these data, still, there is insufficient information to give the current conservation status of this species. Surveys are to be conducted in other places where this species was previously collected. Hence, we herein propose this species to be treated as Data Deficient (DD).

Specimens examined: Philippines. Divilacan, Isabela Province, Northern Sierra Madre Natural Park, $17^{\circ} 19^{\prime} 47^{\prime \prime N}, 122^{\circ} 20^{\prime} 28^{\prime \prime E}, 30$ July 2019, R. Biag RB086 (USTH); Sibuyan Island, Punong Mt., on Jaosan-Punong River trail, 19 May 1987, Sohmer 12393 (BISH); Sibuyan Island, Mt. Giting-giting on a forested ridge, May 1910, 
Elmer 12439 (GH); Guimaras Island, Buenavista-Bo. Tubod, Sulit PNH 11727 (A, K, L).

Notes: Based on overall morphology, this species shows similarities to Psychotria crassifolia. However, differences can still be cited between the two. Greenish brown leaves when dry and fruits, which are 6-8 $\mathrm{mm}$ long for $P$. gitingensis as contrasted with shiny reddish-brown leaves and longer fruits $(8-10 \mathrm{~mm})$ for $P$. crassifolia.

Psychotria nitens Merr. Enum Philipp. Fl. Pl. 3: 560. 1923.

TYPE: Philippines. Luzon: Isabela Prov.: Palanan Bay, 25 Jun 1913, Escritor BS 21157 (lectotype, designated by S. H. Sohmer [1986], K [barcode] 000777426 digital image!).

Description: Shrub, $1 \mathrm{~m}$ tall. Stipules lanceolate, $1 \mathrm{~cm}$ long. Leaves: petioles $1.7-2.5 \mathrm{~cm}$ long; leaf blades ovate to oblanceolate, 11.6-19.4 × 3.2-6.1 cm, coriaceous, drying shiny yellow-brown to orange, glabrous above and below; secondary veins $12-17$ pairs; tertiary venation prominent; base acute, apex acute. Infructuscences trichotomous, 6.3 $\mathrm{cm}$ long. Fruits smooth, yellow; pyrenes ribbed in the outer surface; endosperm ruminate.

Distribution: Endemic to the Philippines, and it has been found in the two municipalities of Isabela, Divilacan, and Maconacon, and also present in Benguet, Cagayan, Quezon, and Samar (Sohmer and Davis 2007).

Habitat: Lowland dipterocarp rainforest at an elevation of $32 \mathrm{~m}$ asl.

Phenology: Observed fruiting in July.

Year last collected: 1981

Vernacular name: none

Conservation Status: Preliminary assessment, according to IUCN by Sohmer and Davis (2007), revealed that this species is Near Threatened (NT). We herein propose this species to be treated as DD. Additional distributional data are still needed to come up with its current assessment. As baseline information, our study reveals that five individuals of this species and some are located near a road, and its proximity to it makes this species more vulnerable to human disturbance. These attributes could be threats resulting in a decline or complete disappearance of these species.

Specimens examined: Philippines. Divilacan, Isabela Province, Northern Sierra Madre Natural Park at $17^{\circ} 19^{\prime} 50^{\prime \prime N}, 122^{\circ} 20^{\prime} 23 " E, 30$ July 2019, R. Biag RB084 (USTH); Isabela Province, Mt. Moises, March 1926, Ramos and Edano 47265 (US); Tayabas, Mt. Binuang, May 1917, Ramos and Edano 28615 (US)

Notes: It's shiny, yellowish-brown leaves, when dry, makes it identifiable from other Psychotria.

Psychotria pilosella subsp. erythrotricha var. erythrotricha (Elmer) Sohmer and Davis, Sida Bot. Misc. 27: 191. 2007.

TYPE: Philippines. Mindanao: Agusan Prov.: Mt. Urdaneta, Aug 1912, Elmer 13486 (lectotype, K designated by S. H. Sohmer [1985]).

Description: Small tree, 5-7 m tall. Stipules valvate, ovate, $4 \mathrm{~mm}$ long, densely pubescent along margins. Leaves: petioles $0.8-3.5 \mathrm{~cm}$ long, pubescent; leaf blades elliptic, obovate to narrowly oblanceolate, $5-18 \times 16-.3 \mathrm{~cm}$, chartaceous, densely hairy below and along the veins above, lateral veins 6-18 pairs, base acute; apex acuminate to acute. Infructescences trichotomous, $6.5 \mathrm{~cm}$ long. Fruit turbinate, $8-10 \mathrm{~mm}$ long, ribbed, distinctly wrinkled when dry, yellow, sparsely to densely pubescent, calyx limb and lobes persistent, pyrene ribbed on outer surface; endosperm ruminate.

Distribution: Endemic to the Philippines and presently a known species in Divilacan, Isabela. Also colonizes Central Luzon through Samar, Panay \& Leyte to Mindanao (Sohmer and Davis 2007).

Habitat: Lowland dipterocarp rainforest at an elevation of $29 \mathrm{~m}$ asl.

Phenology: Observed fruiting in July.

Year last collected: 1995

Vernacular name: Tuyananbaw.

Conservation status: This is an NT species initially assessed by Sohmer and Davis (2007) using the IUCN criteria. Only a single individual of the species has been found all over the surveyed sites, and it's near an accessible waterfall where people could relax and unwind. These factors could threaten this species. We propose, however, the same assessment as DD due to lack of information about the species existence on the area where they were previously collected.

Specimens examined: Philippines. Divilacan, Isabela Province, Northern Sierra Madre Natural Park at 17²19'39"N, 122²0'27"E, 30 July 2019, R. Biag RB089 (USTH); Camarines Norte Province, Bicol National Park, 18 May 1949, E. Canicosa 9763 (BISH); Leyte Province, 15 September 1913, C.A. Wenzel 530 (US); Samar Province, Mt. Sohotan, Babasian Na Daku River, April 1970, Gutierrez et al. 117680 (L)

Notes: The presence of hairs restricted in the midrib of the upper surface of the leaves made us associate this species with Psychotria pilosella subsp. pilosella var. samarensis. However, thorough examinations of the lower surface of the leaves proved that it is also pubescent, particularly along the veins.

Psychotria pubilimba Quisumb. Philipp. J. Sci. 41: 366. 1930.

TYPE: Philippines. Luzon: Isabela Prov. San Mariano, 1 Mar 1926. Ramos \& Edano BS 47221 (lectotype, designated by S. H. Sohmer [1985], A [barcode] 00095520 digital image!; isolectotypes, BM [barcode] 000945499 digital image!, NY [barcode] 00132994 digital image!).

Description: Shrub, $1 \mathrm{~m}$ tall. Stipules imbricate, lanceolate, $0.8 \mathrm{~cm}$ long. Leaves: petioles $1.5-1.7 \mathrm{~cm}$ long; leaf blades lanceolate, $11.5-22.3 \times 2.5-6.4 \mathrm{~cm}$, coriaceous, dark reddish-brown when dry, glabrous above and minutely puberulous in midrib and lateral veins below; secondary veins $18-27$ pairs; tertiary venation prominent; base acute to obtuse; apex long acuminate. Infructescences trichotomous, $2.6 \mathrm{~cm}$ long. Fruits obovoid, $4-5 \mathrm{~mm}$ long, ridged, green, glabrous; calyx limb and lobes persistent; pyrene weakly ridged on outer surface; endosperm ruminate. 
Distribution: Endemic to Northern Luzon, particularly in Cagayan and Isabela. It was mainly found in Maconacon, Isabela (Sohmer and Davis 2007).

Habitat: Lowland dipterocarp rainforest at an elevation of $45 \mathrm{~m}$ asl.

Phenology: Observed fruiting in July.

Year last collected: 1992

Vernacular name: Katagpong-mabolo.

Conservation Status: Being a Narrow Endemic Species (NES), since it is restricted in Cagayan and Isabela provinces, and also found to have only one mature individual in the entire study sites would imply its qualification under the category CR. Hence, our proposal. These attributes make $P$. pubilimba especially prone to extinction, as evident in its population size. It is inherently vulnerable due to its limited distributions in which these zones are also experiencing high levels of environmental degradation. It was directly observed that people still have access to the park, as evidently seen in the cut trees scattered within the park despite the area being a protected zone. Moreover, the frequent occurrence of typhoons in the area is also a driving force for losing this species. Sohmer and Davis (2007) previously assessed this species as EN.

Specimens examined: Philippines. Maconacon, Isabela Province, Northern Sierra Madre Natural Park at 17²1'29"N 12214'1"E, 30 July 2019, R. Biag RB107 (USTH); Palanan, Isabela Province, Sierra Madre Mountains, 11 May 1961, Gutierrez 18259 (L)

Notes: As to its taxonomy, Sohmer (2007) argued its fruits, particularly its pyrenes. He couldn't verify whether the initial description given by Quisumbing (1930) as regards the pyrenes is correct or not. Our findings strongly support Sohmer's description revealing that the pyrenes of $P$. pubilimba are weakly ridged, which is contrary to a smooth pyrene as initially described by Quisumbing. This species rediscovery puts a halt to that confusion. It is in this note that a provision of a conclusive statement as regards the pyrenes of this species is highly recommended.

Psychotria reynosoi Sohmer \& A.P.Davis, Sida Bot. Misc. 27: 191. 2007.

TYPE: Philippines. Luzon: Zambales Prov.: Mt. Marayep, 9 Dec 1924. Ramos \& Edano BS 44808 (isotype, $\mathrm{K}$ [barcode] 000777439 digital image!).

Description: Small tree, $4 \mathrm{~m}$ tall. Stipules lanceolate, $2.4 \mathrm{~cm}$ long. Leaves: petioles $2.1-3.0 \mathrm{~cm}$ long; leaf blades elliptic, $8.5-19.4 \times 2.5-8.1 \mathrm{~cm}$, coriaceous, khaki-green when dry, glabrous above and below; secondary veins 9-15 pairs; tertiary venation prominent; base obtuse to acute; apex acute to acuminate. Infructescences trichotomous, 6.5 $\mathrm{cm}$ long, principal axis $5 \mathrm{~cm}$ long, each axis with three primary nodes and verticillate branching at each node. Fruits globose, $11 \mathrm{~mm}$ long, coarsely ribbed, orange; pedicels $5 \mathrm{~mm}$ long; pyrenes distinctly ridged on the outer surface, endosperm ruminate.

Distribution: It is a Luzon-endemic species, found mainly in Northern and Central Luzon (Sohmer and Davis 2007). In this study, only the municipality of Palanan, Isabela, has been observed to harbor this species.
Habitat: Lowland dipterocarp forest at an elevation of $124 \mathrm{~m}$ asl.

Phenology: Observed flowering and fruiting in April.

Year last collected: 1995

Vernacular name: Reynoso-katagpo.

Conservation status: Like the previously mentioned species, $P$. reynosoi is herein proposed to be treated as DD. Only one individual was found in the park. Botanical surveys should be done in areas where this species was once found. Following IUCN, Sohmer and Davis (2007) initially assessed it as NT.

Specimens examined: Philippines. Palanan, Isabela Province, Northern Sierra Madre Natural Park at $17^{\circ} 2^{\prime} 21^{\prime \prime}$ N, 122 23'14"E, 30 July 2019, R. Biag RB099 (USTH); Isabela Province, Mt. Moises, March 1926, Ramos and Edano 47288 (US); Tayabas, Mt. Binuang, May 1917, Ramos and Edano 28568 (US)

Notes: Morphologically, it resembles the $P$. pallidifolia through its elliptic, khaki-green color leaves when dry, trichotomous infructescence, and coarsely ribbed fruits. Its globose and longer fruits $(11 \mathrm{~mm})$ delineates it from $\mathrm{P}$ pallidifolia with turbinate, $5 \mathrm{~mm}$ long fruits.

Psychotria rubiginosa Elmer ex Merr. Enum. Philipp. Fl. Pl. 3: 562. 1923.

TYPE: Philippines. Luzon: Bataan Prov.: Mt. Mariveles, Nov 1904, Elmer 6718 (lectotype, K, Us [barcode] 02738035 digital image!).

Description: Small tree, $5 \mathrm{~m}$ tall. Stipules valvate, ovate, $0.9 \mathrm{~cm}$ long. Leaves: petioles $.8-2.2 \mathrm{~cm}$ long, leaf blades oblong to oblanceolate, 11.5-18.2 $\times 3.5-5.9 \mathrm{~cm}$, glabrous above and below, coriaceous, yellow-brown when dry; secondary veins 12-15 pairs; tertiary venation manifest; base acute; apex acute. Infructescences monochotomous, $8 \mathrm{~cm}$ long. Fruits globose, $7 \mathrm{~mm}$ long, ridged, yellow, glabrous; pedicels 1-2 mm; pyrenes ridged on outer surface; endosperm ruminate.

Distribution: Endemic to the Philippines, but mainly in Luzon and in this study, was found in Divilacan, Isabela. One has been recorded in Cebu (Sohmer and Davis 2007).

Habitat: Lowland dipterocarp rainforest at an elevation of $69 \mathrm{~m}$ asl.

Phenology: Observed fruiting in July.

Year last collected: 1993

Vernacular name: Katagpong-pula.

Conservation status: The same assessment (DD) as the other species is given for $P$. rubiginosa, for it requires further surveys for additional distributional data. Our data reveal five mature individuals present in the park. Sohmer and Davis (2007) originally assessed it as NT.

Specimens examined: Philippines. Divilacan, Isabela Province, Northern Sierra Madre Natural Park at 17²19'43"N12220'29"E, 30 July 2019, R. Biag RB087 (lectotype, PNH; isolectotype, USTH); Bataan Province, Mt. Palacio, December 1947, Edano 4124 (PNH)

Notes: This species can be distinguished from other Psychotria species through its oblong to oblanceolate leaves, monochotomous infructescence, and long peduncle $(5 \mathrm{~cm})$. 
Psychotria subsessiliflora var. carinata (Quisumb. \& Merr.) Sohmer \& A.P.Davis, Sida Bot. Misc. 27: 79. 2007.

TYPE: Philippines. Luzon: Quezon Prov.: Casiguran, 28 May 1925. Ramos \& Edano BS 45278 (lectotype, designated by S. H. Sohmer, US [barcode] 1595125 digital image!; isolectotypes, A [barcode] 00095475 digital image!, NY [barcode] 00132908 digital image!).

Description: Shrub, $4 \mathrm{~m}$ tall. Stipule valvate, triangular, $0.5 \mathrm{~cm}$ long. Leaves: petioles $1.8-2.4 \mathrm{~cm}$ long; leaf blades elliptic to obovate, $13.3-16.6 \times 4.7-6.8 \mathrm{~cm}$, coriaceous, grayish brown, glabrous above and hairy below; secondary veins 11 pairs; tertiary venation manifest to obscure; base acute; apex acuminate to acute. Infructescences trichotomous, $2 \mathrm{~cm}$ long, with two small branches from the base of the main axis with 2 clusters of sessile fruits. Fruits obovoid, $8 \mathrm{~mm}$ long, ribbed, distinctly wrinkled when dry; pedicels absent; pyrenes ribbed to smooth; endosperm ruminate.

Distribution: It was found thriving in Divilacan, Isabela. Also, it colonizes other parts of Luzon like Cagayan, Aurora, Rizal, Camarines, and Catanduanes. Hence, a Luzon-endemic variety (Sohmer and Davis 2007).

Habitat: Lowland dipterocarp forest at an elevation of $17 \mathrm{~m}$ asl.

Phenology: Observed fruiting in July.

Year last collected: 1961

Vernacular name: Katagpong-gulod.

Conservation Status: At present, this species is categorized as DD based on IUCN criteria. A singular individual was only found in our sites. Sohmer and Davis (2007) initially assessed it as NT.

Specimens examined: Philippines. Divilacan, Isabela Province, Northern Sierra Madre Natural Park at $17^{\circ} 19^{\prime} 55^{\prime \prime N}$, 122 20'20"E, 30 July 2019, R. Biag RB081 (USTH); San Mariano, Isabela Province, Sierra Madre Mountains, April-May 1961, H.G. Gutierrez 78165 (L); Casiguran, Tayabas, May-June 1925, Ramos and Edano 45278 (BISH)

Notes: As its name implies, the chief distinguishing characteristics of this species is its sub-sessile fruits, which are evidently wrinkled when dry.

Psychotria tayabensis Elmer var. euphlebia (Merr.) Sohmer \& A.P.Davis, Sida Bot. Misc. 27: 84. 2007.

TYPE: Philipines. Panay: Capiz Prov.: Jamindan, AprMay 1918, Ramos \& Edano BS 31224 (lectotype, designated by S. H. Sohmer [1985], A [barcode] 00095537 digital image!; isolectotype, K [barcode] 000777315 digital image!).

Description: Shrub, ca $1 \mathrm{~m}$ tall. Stipules triangular, 0.5 cm long. Leaves: petioles 1-2 cm long; leaf blades elliptic, 12.7-14.3 × 3.9-5.3 cm, secondary veins 13-15 pairs; tertiary venation obscure to manifest; base acute; apex abruptly acuminate. Infructescences simple (much reduced), $2.6 \mathrm{~cm}$ long, short main axis present, lateral axes and branches absent. Fruits globose, 5 mm long, sessile.

Distribution: A Philippine endemic particularly found in the municipality of Cabagan, Isabela and also Quezon, Camarines, Apayao, Alabat, and Panay Islands (Sohmer and Davis 2007).
Habitat: Lowland dipterocarp forest at an elevation of $124 \mathrm{~m}$ asl.

Phenology: The species was observed fruiting in May.

Year last collected: 1995

Vernacular name: Tayabas-katagpo.

Conservation Status: According to IUCN rules, this species should be treated as DD for it lacks data in terms of their distribution other than our surveyed sites. In the current study, only one individual was found, and we observed that the area was not spared from illegal logging and slash and burn farming was still practiced. Initially, it was assessed NT by Sohmer and Davis (2007).

Specimens examined: Philippines. Cabagan, Isabela Province. Northern Sierra Madre Natural Park at $17^{\circ} 26^{\prime} \mathrm{N} 121^{\circ} 46^{\prime} \mathrm{E}$ 124, 30 May 2019, R. Biag RB069 (USTH); Sangcad, Palanan, Isabela Province, 11 May 1961, H. Gutierrez 78268 (L); Alabat Island, SeptemberOctober 1926, Ramos and Edano 48228 (US)

Notes: This species can be distinguished from other Psychotria species through its non-prominent tertiary venation, pubescent petiole and globose, sessile fruits.

\section{New records in the national park}

Antirhea benguetensis (Elmer) Valeton, Bull. Dep. Agric. Indes Neerl. 26 (1909) 32. Figure 4

TYPE: Philippines. Benguet Province. Twin peaks, on bluffs along Bued Rivers, May 1904, Elmer PNH 6396 (lectotype, NY [barcode] 00133416 digital image!, isolectotype, $\mathrm{K}$ [barcode] 000763544 digital image!).

Description: Shrub, $2 \mathrm{~m}$ tall. Branchlets pubescent and tomentose. Stipules valvate, deltate, $4.5 \times 11 \mathrm{~mm}$, apex aristate. Leaf blades elliptic, 5.6-11 $\times 2.6-6.5 \mathrm{~cm}$, chartaceous, adaxial and abaxial sides pubescent but densely pubescent in the latter; base rounded; apex acuminate; costa prominent and raised beneath; secondary veins nine pairs; tertiary venation immersed beneath; domatia obscure in leaf axils. Infructescence $5.5 \mathrm{~cm}$ long. Fruits ellipsoid, 7-8 mm long, tomentose; calyx persistent, $2 \mathrm{~mm}$ long; bracts acicular, persistent, $5.0 \times 0.1 \mathrm{~mm}$; 4 ribbed; pyrenes $>3$.

Distribution: Endemic to Luzon (Salamanes 2014), and this study reveals its presence in the municipality of Divilacan, Isabela. Also, in Benguet, Ilocos Sur, Rizal, and Bataan.

Habitat: Lowland dipterocarp rainforest at an elevation of $76 \mathrm{~m}$ asl.

Phenology: Observed fruiting on July

Specimen examined: Philippines. Divilacan, Isabela. Northern Sierra Madre Natural Park at 17'19'9" N, 122²0'6"E, 30 July 2019, R. Biag RB099 (USTH); Rizal Province, Mt. Susong-Dalaga, August 1917, Ramos and Edano 29343 (US); Rizal Province, September 1905, Ahern's Collector 3302 (US)

Notes: This species is distinguishable from other species of Antirhea through its densely pubescent leaf blades, particularly on the abaxial side (Salamanes 2014) (Figure 4). Discovery of it in NSMNP specifically in Divilacan, Isabela, means that its area of distribution has expanded. 
Ixora longifolia Smith, A. Rees, Cycl. 19 (1811) 3. Figure 5

TYPE: Indonesia. Island of Honimoa, 1797, Smith s.n. (lectotype, LINN [microfiche], designated by Turner (2013); isolectotype, BM).

Description: Shrub, $2 \mathrm{~m}$ tall. Stipules persistent, sheath widely triangular, $2 \mathrm{~mm}$ long, awn $3 \mathrm{~mm}$ long. Leaves: petioles $1 \mathrm{~cm}$ long; leaf blades lanceolate, 15-22.9 × 2.2$3.9 \mathrm{~cm}$, coriaceous, drying dark brown, paler below; base cuneate; apex acute to long acuminate; secondary veins 12 each side. Inflorescences terminal, shortly pedunculate, trichotomously branched, peduncle $3 \mathrm{~cm}$ long; central first order axis $2 \mathrm{~cm}$ long; lateral first order $3.5 \mathrm{~cm}$ long; firstorder bracts with stipular parts present fused to an ovate blade with a central awn and foliar parts widely triangular and vaulted; higher bracts with stipular parts absent and foliar parts triangular and vaulted. Ultimate flower triads with flower subsessile; corolla bright red; bracteoles $1 \mathrm{~mm}$ long present on most pedicels; calyx tube $0.5 \mathrm{~mm}$ long; calyx lobes triangular, apices acute; corolla tube $28 \mathrm{~mm}$ long; corolla lobes lanceolate, $0.8 \times 2.5 \mathrm{~mm}$, apices acute.

Distribution: Found in the municipality of Divilacan, Isabela. Mostly distributed in the provinces of Visayas and Mindanao, and Palawan. Also occurring in China, India, Myanmar, Indonesia, Malaysia, and Vietnam (Banag 2014).

Habitat: Lowland dipterocarp rainforest at an elevation of $46 \mathrm{~m}$ asl.

Phenology: Observed fruiting and flowering in July.

Specimen examined: Philippines. Divilacan, Isabela Province, Northern Sierra Madre Natural Park at $17^{\circ} 19^{\prime} 34^{\prime \prime N}$, 122²0'22"E, 30 July 2019, R. Biag RB093 (USTH); Masbate Province, 2 March 1994, Barbon et al. 12527 (L); Cebu Province, Camp 7 (lower), Minglanilla (ERDS), 14 June 1997, Gaerlan and Reynoso 20383 (K, L)

Notes: Morphologically, I. longifolia resembles I. salicifolia, but a careful investigation of our specimen reveals that the leaves of the former never appear linear, a leaf shape assumed by the latter (Banag 2014) (Figure 5). As to its distribution in Luzon, it mentioned only of Palawan and Masbate, but our data manifest that $I$. longifolia also colonizes Northern Luzon in Divilacan, Isabela, in particular.

\section{Discussion}

All the eight taxa of Psychotria collected are Philippine endemics, as verified in the study of Alejandro (2007) and the Co's Digital Flora of the Philippines (Pelser et al. 2011). Among species with narrow ranges, endemic species are of particular concern since they are confined to a particular geographic area and may have small population sizes associated with a relatively high risk of extinction (Ndayishimiye et al. 2012; Banag et al. 2015). Conduct of a floristic survey like this is a must to update the conservation status of Philippine flora, especially our endemics.

The most recent collections of Rubiaceae was done by Ordas et al. (2019) in Eastern Samar from June 2013 to June 2017. Six Psychotria spp. were identified, and three species and varieties (Psychotria conglomeratiflora Sohmer \& Davis, Psychotria paloensis var. subelliptifolia
Sohmer \& Davis \& Psychotria wenzelii (Merr.) Merr.) are CR, two (Psychotria papillata (Merr.) Merr. \& Psychotria radicans (Merr.) Merr.) are VU, and one (Psychotria membranifolia Bartl. ex D.C.) is NE. The species were assessed using the preliminary conservation assessment by Sohmer and Davis (2007) based on the IUCN criteria.

Botanical exploration in NSMNP was conducted in 1991, and a total of 241 woody species in 58 families and 118 genera were recorded consisting of eight lianas, 65 shrubs and 168 small to large trees. The most speciose families are Myrtaceae (35 spp.), Rubiaceae (21 spp.), Phyllantacea (17 $\mathrm{spp}$.$) , Sapotaceae (16 \mathrm{spp}$.$) and$ Euphorbiaceae (14 spp.) Among those Rubiaceous plants collected were Psychotria (Guingab and van Welzen 2018). No recent collections have been made since then, as evident in the specimens observed in the different herbaria. Now we are presenting them as species that have survived the inescapable catastrophes in the park. All the species were initially collected in San Mariano and Palanan, Isabela, areas covered by the NSMNP. Though our data suggest that these floras, except for P. reynosoi, were not seen in the previously known collection sites, it is worth noting that the present zones, Divilacan and Maconacon, Isabela where these species were found, are near Palanan, all of which are coastal areas covered by the park. Meanwhile, $P$. tayabensis var. euphlebia was collected in Cabagan, Isabela, a non-coastal zone.

The geographical distribution of species is crucial in assessing their conservation status. What becomes interesting in this study is the rediscovery of Psychotria pubilimba, a species restricted to Cagayan and Isabela. It was last collected in San Mariano and Palanan, Isabela, in 1992. After 28 years, this EN species, as previously assessed by Sohmer and Davis (2007) using the IUCN criteria, has been recollected in Maconacon, Isabela. It merely means that its geographical distribution has expanded. An exhaustive survey was carried out by us in those places, as mentioned above, but unfortunately, $P$. pubilimba was only discovered in Maconacon.

According to Wulff et al. (2013), species occurring in three or fewer locations are considered Narrow Endemic Species (NES). On top of having a narrow geographical range, they are also known to have only one or a few populations, small population size, and little genetic variability (Isik 2011). Our data reveal the presence of only one mature individual of $P$. pubilimba in the surveyed site. Given these available data and information, $P$. pubilimba can be assessed as critically endangered (CR) based on IUCN criteria. This species being an NES must be given priority and monitored and managed carefully to promote genetic conservation.

In this study, all the Psychotria studied except $P$. pubilimba were placed under the category Data Deficient following the IUCN criteria. Further surveys should be conducted in areas where these Psychotria were previously collected to give its current assessment. The preliminary assessment using IUCN rules (Sohmer and Davis 2007) of each plant was still provided in the current study. 

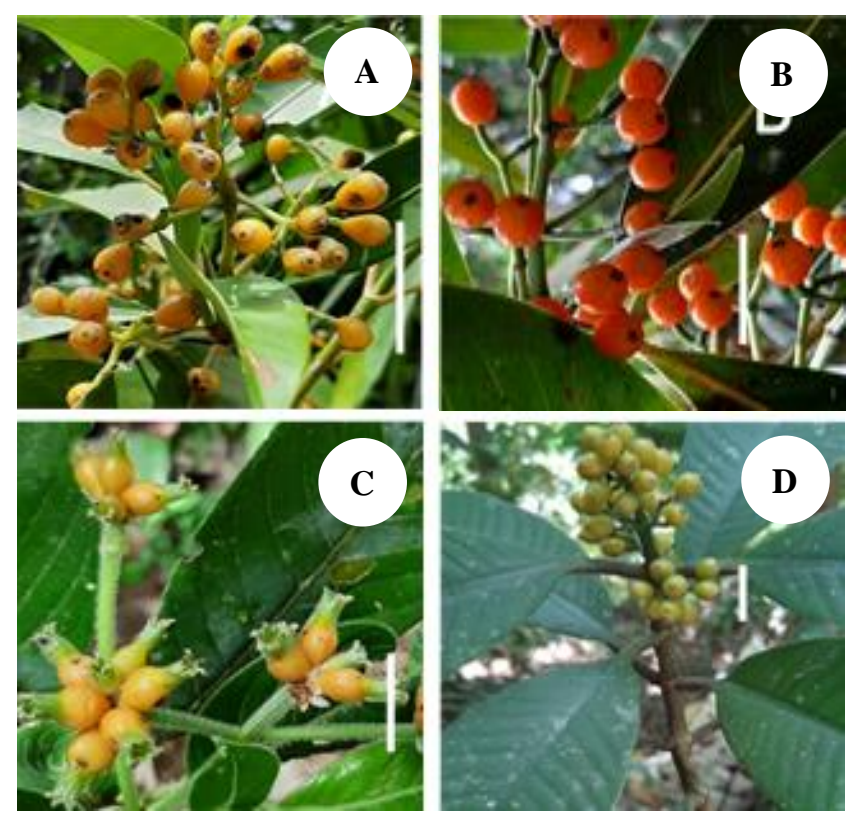

Figure 2. Fruiting branches of Psychotria species collected in Divilacan (A, B, C) and Macanocan (B, D), Isabela. A. Psychotria gitingensis, B. Psychotria nitens, C. Psychotria pilosella ssp. erythtricha var. erythtricha, D. Psycothrica publimba. Photos taken by R. Biag. Scale Bars: $A=5 \mathrm{~cm}, B=3 \mathrm{~cm}, C=3 \mathrm{~cm}, \mathrm{D}=$ $1 \mathrm{~cm}$.
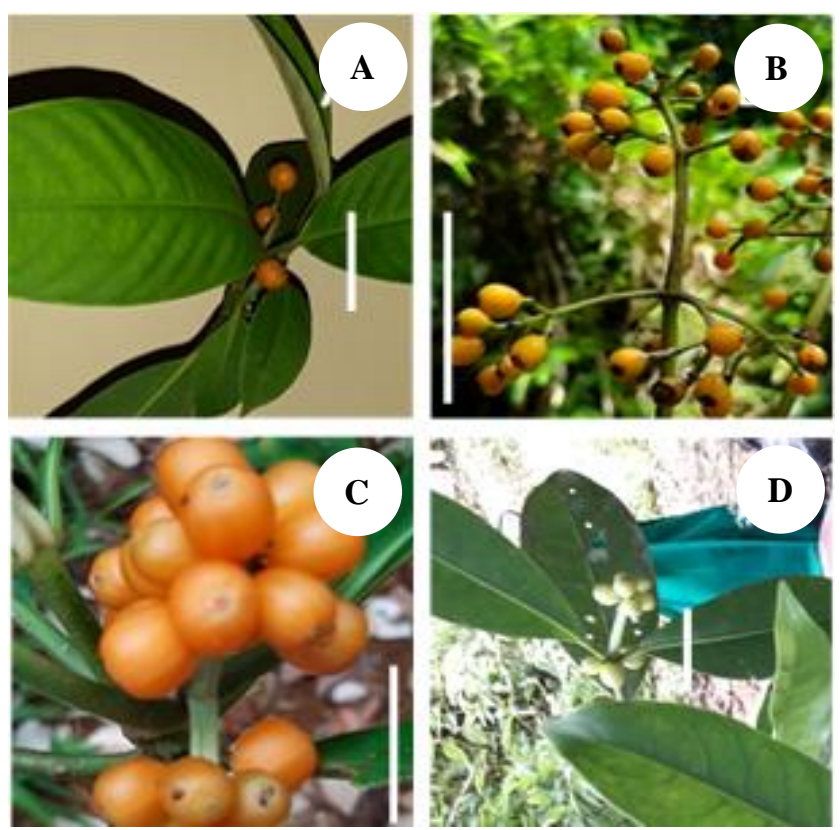

Figure 3. Fruiting branches of Psychotria species collected in Cabagan (D), Divilacan (B, C), \& Palanan (A), Isabela. A. Psychotria reynososoi, B. Psychotria rubiginosa, C. Psychotria subsessiliflora var. carinata, D. Psycothrica tayabensis var. euphlebia. Photos taken by R. Biag. Scale Bars: $A=5 \mathrm{~cm}, \mathrm{~B}=5$ $\mathrm{cm}, \mathrm{C}=1 \mathrm{~cm}, \mathrm{D}=2 \mathrm{~cm}$.
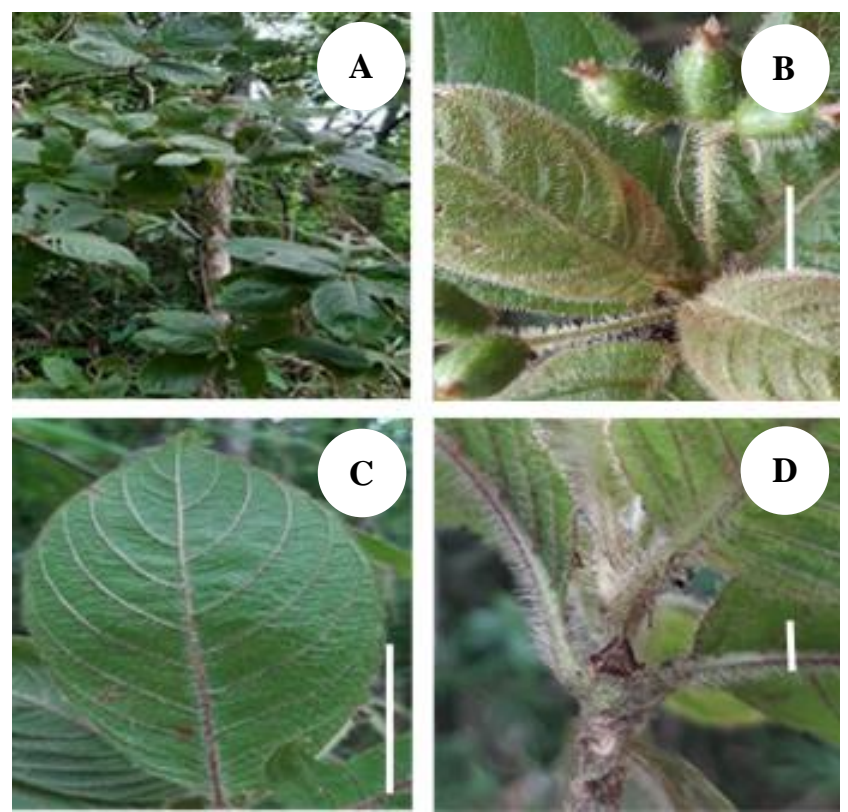

Figure 4. Antirhea benguetensis collected in Divilacan, Isabela. A. Habitat, B. Infructescence showing ellipsoid and tomentose fruits, C. Abaxial leaf surface with much pubescence, D. Triangular stipule and densely pubescent petiole. Photos taken by R. Biag. Scale Bars: $B=2 \mathrm{~cm}, C=5 \mathrm{~cm}, D=5 \mathrm{~mm}$.
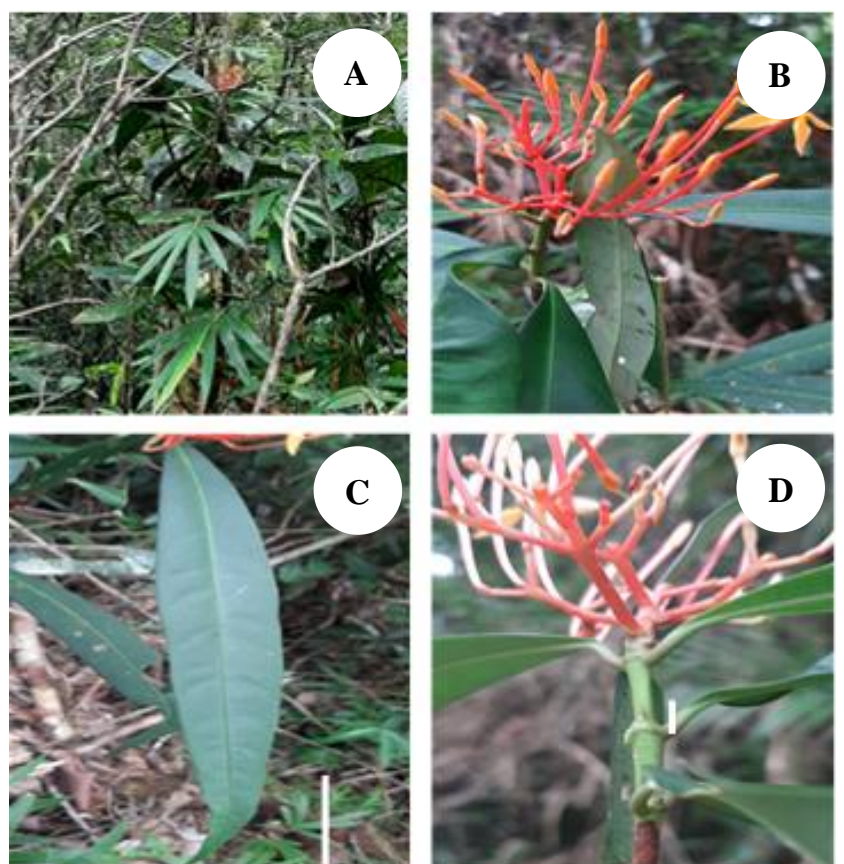

Figure 5. Ixora longifolia collected in Divilacan, Isabela. A. Habitat, B. Infructescence showing a flower with lanceolate corolla lobes, Clanceolate leaf, D. Widely triangular stipule. Photos taken by R. Biag. Scale Bars: C $=5 \mathrm{~cm}, \mathrm{D}=5 \mathrm{~mm}$. 
Series of floristic surveys done in this national park in the 1990s by the Conservation International-Philippines revealed that Antirhea benguetensis and Ixora longifolia are species not previously known in the NSMNP. The former is known to occur only in Ilocos Sur, Benguet, Bataan, Rizal and Batangas (Salamanes 2014), while the latter mostly occurs in Visayas and Mindanao and only Masbate and Palawan for Luzon (Banag 2014). Our study has proven that the park harbor these species of Rubiaceae. Hence, they have considered two new records in the area. Unfortunately, only one mature individual of $A$. benguetensis was observed. It calls, therefore, for an act of protection and conservation. More individuals of $I$. longifolia were noticed than A. benguetensis. However, climate change by 2020 and 2050 will likely affect Philippine flora and fauna (PAGASA 2011). Numerous ecological studies have now pointed to an important general pattern of species responses to climate change around the world (Yang and Rudolf 2010).

Observed temperature in the Philippines is warming at an average of $0.1^{\circ} \mathrm{C} / \mathrm{decade}$. It is projected that the countryaveraged mean temperature could increase by as much as $0.9^{\circ} \mathrm{C}-1.9^{\circ} \mathrm{C}$ in the mid-21st century $(2036-2065)$. In terms of the annual and seasonal rainfall, increasing trends were observed in various parts of the country (PAGASA 2018, 2020). Nevertheless, projected changes in rainfall could be within the natural rainfall variations, except for the central sections of Mindanao, where there is a projected rainfall reduction (Banag et al. 2015; PAGASA 2018). A slight decrease in the number of tropical cyclones (TCs) and a minimal increase in the frequency of very strong (TCs) have been noticed in the Philippine area of responsibility in the past 65 years (1951-2015) (PAGASA 2018, 2020). These climate trends and projected climate change in the country posed a serious threat to biodiversity, besides deforestation, because it can cause significant impacts on the distribution of species and the composition of habitat (Barve et al. 2011; Trisurat et al. 2011; Banag et al. 2015). Ixora is just among these plants, which can be significantly affected. Banag et al. (2015) has proven in her study focused on Ixora as affected by climate change that $I$. auriculata Elmer and I. bartlingii Elmer are vulnerable to such change, which will eventually lead to the shrinkage or shift in geographical range. This will be evident in Luzon due to the increasing extreme rainfall in the coming years as projected by PAGASA and exposure to tropical cyclones (Yusuf and Francisco 2009). The loss of suitable areas in Luzon will then enable the Ixora species to shift to potential zones towards the western Visayas and Mindanao (Banag et al. 2015). However, Garcia et al. (2014) pointed out that mitigating local impacts through reduction of habitat loss and enhancement of habitat quality or heterogeneity can be vital in areas where shrinking climates reduce opportunities for species survival outside present ranges, particularly for climatically specialized species.

It's a sad thing to note that much of NSMNP, although "protected on paper," is still under considerable threat. Residents slowly encroach on the park from different areas to do illegal logging. Slash and burn farming and timber, and wildlife collections persist (van der Ploeg et al. 2011;
Haribon Foundation for the Conservation of Natural Resources 2016), aside from the fact that the park's resources are equally threatened by the tropical cyclones occurring in the area (Guingab 2019).

Many Psychotria species were found to display bactericidal, antifungal, antiviral, antiprotozoal, antiinflammatory, antioxidant and analgesic activities and act positively on neurodegenerative diseases (Talbot et al. 2013; Calixto et al. 2016; Tran et al. 2017). On the other hand, Antirhea has anti-inflammatory and antioxidant properties (Sage et al. 2017) while Ixora species have been documented for various medicinal properties such as anticancer, antibacterial, antifungal, anthelmintic, antidiarrheal, antileishmanial, anti-asthma, anti-inflammatory, and anti-ulcer, to name a few (Wahab et al. 2012; Yoga et al. 2012; Rajendra et al. 2013; Dontha et al. 2015). Nonetheless, the taxa included in this study are yet to be investigated for their medicinal properties. Hence, these plants are to be protected and conserved.

Continuous exposure of these species to natural and human-induced forest degradation activities will eventually qualify them for extinction. As the figure representing the number of individuals per species is alarming, it emphasizes the urgent need for effective in situ and ex situbased conservation actions. Our study highlights the importance of species rediscovery, which is secondary to intense fieldwork. Indeed, species rediscovery is possible. Such rediscovery brings hope amidst the crisis our biodiversity is encountering.

As a result of series of surveys in the NSMNP, 89 Rubiaceae species were collected and were dominantly represented by the genus Psychotria. Five species (Psychotria gitingensis Elmer, Psychotria nitens Merr., Psychotria pubilimba Quisumb., Psychotria reynosoi Sohmer \& A.P.Davis, and Psychotria rubiginosa Elmer ex Merr.), one subspecies (Psychotria pilosella subsp. erythrotricha var. erythrotricha (Elmer) Sohmer and Davis), and two varieties (Psychotria subsessiliflora var. carinata (Quisumb. \& Merr.) Sohmer \& A.P.Davis and Psychotria tayabensis Elmer var. euphlebia (Merr.) Sohmer \& A.P. Davis) of Psychotria were rediscovered since their last discovery in the 1990s. Many decades have elapsed, and the results of this study revealed the existence of these Psychotria up to the present time amidst the catastrophes faced by these floras. According to IUCN criteria, these floras should be treated as DD as regards their conservation status. Additional surveys are needed, especially in those places where these plants were previously collected. Collected data from this study will then serve as baseline information. When combined later on with those data obtained from other surveys, then the current conservation assessment can already be provided. This study also reveals the discovery of Antirhea benguetensis (Elmer) Valeton, endemic, and Ixora longifolia Smith, non-endemic. Although the latter is not endemic in the Philippines (Banag et al. 2017), it still deserves our sense of stewardship for its conservation. Botanical records proved that these species are not previously known in this national park. Hence, this study proposed these two floras as new records in NSMNP. 
Increasing research efforts through the continuous conduct of biological surveys open doors for the reappearance of species. Data results we obtain from botanical studies like this are necessary to inform conservation decisions in the wider area and for the management of protected areas like NSMNP. It is of great essentiality to have these botanical explorations and taxonomic works recognized through prioritized funding opportunities. An excellent means to prevent these species remain little known to science. Relocation of them is urgent, while the multitude of anthropogenic disturbances that drive them to extinction is at hand.

\section{ACKNOWLEDGEMENTS}

The authors are grateful to the directors and curators of PNH, USTH, CAHUP, ISUH for the access of their herbarium collections and $\mathrm{K}, \mathrm{A}, \mathrm{NY}, \mathrm{L}, \mathrm{BM}, \mathrm{GH}, \mathrm{BISH}$, and the US herbaria for the access of digital images. The first author also would like to thank the Commission on Higher Education and Cagayan State University, Carig Campus for the Scholarship Grant. Both authors also acknowledge the Department of Environment and Natural Resources, Region 02, for granting them the gratuitous permit that allowed them to proceed with their field works in the national park.

\section{REFERENCES}

Alejandro GJD, Liede-Schumann S. 2003. The Philippine Rubiaceae genera. Updated synopsis in INTKEY databases of the DELTA system. Blumea 48: 261-277. DOI: 10.3767/000651903X674964.

Alejandro GJD. 2007. The current status of the Philippine Rubiaceae. Philipp J Syst Biol 1 (1): 47-60. DOI: 10.3860/pjsb.v1i1.908.

Banag CI. 2014. Systematics of the Philippine Endemic Ixora L. (Rubiaceae, Ixoreae). [Dissertation]. University of Bayreuth, Bayreuth, Germany.

Banag CI, Thrippleton T, Alejandro GJD, Reineking B, Liede-Schumann S. 2015. Bioclimatic niches of selected endemic Ixora species on the Philippines: predicting habitat suitability due to climate change. Plant Ecol 216: 1325-1340. DOI: 10.1007/s1 1258-015-0512-6.

Banag C, Mouly A, Alejandro G, Bremer B, Meve U, Grimm G, LiedeSchumman S. 2017. Ixora (Rubiaceae) on the Philippines-crossroad or cradle? BMC Evol Biol 17: 131. DOI: 10.1186/s12862-017-0974-3.

Barve N, Barve V, Jimenez-Valverde A, Lira-Noriega A, Maher SP, Peterson AT, Soberon J, Villalobos F. 2011. The crucial role of the accessible area in ecological niche modeling and species distribution modeling. Ecol Model 222: 1810-1819. DOI: 10.1016/j.ecolmodel.2011.02.011.

Barrabé L, Buerki S, MoulyA, Davis A, Munzinger J, Maggial L. 2012. Phylogenetic inference of Asian, Australasian and Pacific Margaritopsis. Taxon 61 (6): 1251-1268. DOI: 10.1002/tax.616007.

Beentje H. 2016. The Kew Plant Glossary: An Illustrated Dictionary of Plant Terms. Richmond: Royal Botanic Gardens, Kew.

Calixto N, Pinto ME, Ramalho S, Burger M, Bobey A, Young MC, Bolzani V, Pinto A. 2016. The genus Psychotria: phytochemistry, chemotaxonomy, ethnopharmacology and biological properties. J Braz Chem Soc 27 (8): 1355-1378. DOI: 10.5935/01035053.20160149.

Chen T, Zhu H, Chen J, Taylor, CM, Ehrendorfer F, Lantz H, Funston AM, Puff C. 2011. Rubiaceae. In: Wu ZY, Raven PH, Hong DY (eds.) Flora of China, 19. Science Press, Beijing and Missouri Botanical Garden, St. Louis.

Davis A, Bridson D, Jarvis C, Govaerts R. 2001. The typification and characterization of the genus Psychotria L. (Rubiaceae). Bot J Linn Soc 135 (1): 35-42. DOI: 10.1111/j.1095-8339.2001.tb02366.x.
Davis AP, Sohmer SH. 2004. Current status of Psychotria (Rubiaceae) in the Philippines. FAO, Rome. agris.fao.org

Davis AP, Govaerts R, Bridson DM, Ruhsam M, Moat J, Brummit N. 2009. A global assessment of distribution, diversity, endemism and taxonomic effort in the Rubiaceae. Ann Mo Bot Gard 96: 68-78. DOI: $10.1006 / \mathrm{bc} \sim \mathrm{j} 1.2000 .03$.

Department of Environment and Natural Resources II. 2017. Northern Sierra Madre Natural Park Profile.

Dontha S, Kamurthy H, Mantripragada B. 2015. Phytochemical and pharmacological profile of Ixora: A review Int J Pharm Sci Res 6 (2): 567-584.

Garcia R, Cabeza M, Rahbek C, Araújo M. 2014. Multiple dimensions of climate change and their implications for biodiversity. Science 344: 6183. DOI: $10.1126 /$ science. 1247579.

GBIF. 1999-onwards. Global Biodiversity Information Facility.https: //www.gbif.org.

Govaerts R. 2011. World Checklist of Rubiaceae. Facilitated by the Royal Botanic Gardens, Kew. Available from: http: //apps.kew.org/wcsp/ [18 February 2020]

Guingab MVD, van Welzen PC. 2018. Woody Plants of the Northern Sierra Madre Natural Park and Vicinity. Isabela State University Publishing, Prints \& Solutions. Isabela.

Guingab MVD. 2019. Richness, endemism and conservation status of woody plants in the lowland forest over limestone of Northern Sierra Madre Natural Park, Northeast Luzon, Philippines. J Biol Environ Sci 14 (5): 135-141.

Haribon Foundation for the Conservation of Natural Resources. 2016. Northern Sierra Madre Natural Park, The country's biggest natural forest.

IPNI. 2020. International Plant Names Index. http: //www.ipni.org.

Isik K. 2011. Rare and endemic species: Why are they prone to extinction?. Turk J Botany 35: 411-417

Koopowitz H, Sohmer S, Thornhill A, Perez G. 1998. Deforestation and plant species extinctions in the Philippines: Psychotria as an example. In: -I Peng C, Lowry P (eds.) Rare, Threatened and Endangered Floras of Asia and the Pacific Rim. Academia Sinica Monograph Series No. 16, Taipei, 111-121.

Mabuwaya Foundation. 2018. The Northern Sierra Madre Natural Park. Mabuwaya Foundation, Inc

Ndayishimiye J, Greve M, Stoffelen P, Bigendako MJ, De Canniere C, Svenning J, Bogaert J. 2012. Modelling the spatial distribution of endemic Caesalpinioideae in Central Africa, a contribution to the evaluation of actual protected areas in the region. Int $\mathbf{J}$ Biodivers Conserv 4: 118-129. DOI: 10.5897/IJBC11.150.

Ordas JAD, Pinarok NAA, Romeroso RB, Alejandro GJD, Banag-Moran CI. 2019. A checklist of Rubiaceae species from Eastern Samar, Visayas, Philippines. Check List 15 (2): 295-312. DOI: 10.15560/15.2.295

PAGASA. 2011. Available at: http: //kidlat.pagasa.dost.gov.ph/cab/climate_change/ [25 March 2020]

PAGASA. 2018. Observed and Projected Climate Change in the Philippines. Philippine Atmospheric, Geophysical and Astronomical Services Administration, Quezon City, Philippines.

PAGASA. 2020. Climate Review. Philippine Atmospheric, Geophysical and Astronomical Services Administration, Quezon City, Philippines.

Pelser P, Barcelona J, Nickrent D. 2011. Co's Digital Flora of the Philippines. http: //www.philippineplants.org. [1 February 2020].

Plants of the World Online. 2020. Facilitated by the Royal Botanic Gardens, Kew. Published on the Internet; http: //www.plantsoftheworldonline.org/ [28 September 2020].

Rajendra K, Nitin G, Mahavir G, Sudhir V, Mangesh K. 2013. Evaluation on anti-inflammatory and antioxidant potential of Ixora coccinea Linn ethanolic root extract. Int J Drug Dev Res 5: 1-10.

Razafimandimbison S, Taylor C. Wikström N, Pailler T, Khodabandeh A, Bremer B. 2014. Phylogeny and generic limits in the sister tribes Psychotrieae and Palicoureeae (Rubiaceae): evolution of schizocarps in Psychotria and origins of bacterial leaf nodules of the Malagasy species. Am J Bot 1102-1126. DOI: 10.3732/ajb.1400076.

Sage F, Meilhac O, Gonthier MP. 2017. Anti-inflammatory and antioxidant effects of polyphenols extracted from Antirhea borbonica medicinal plant on adipocytes exposed to Porphyromonas gingivalis and Escherichia coli lipopolysaccharides. Pharmacol Res 119: 303312. DOI: 10.1016/j.phrs.2017.02.020. 
Salamanes, JJDP. 2014. Novelties in the tribe Guettardeae (Rubiaceae) Inferred from Molecular (nrDNA) and Morphological Data. [Thesis]. University of Santo Tomas, Manila. [Philippines].

Sohmer SH. 2001. Conservation lessons from studies in Philippine Psychotria. Malayan Nat J 55: 43-47.

Sohmer SH, Davis AP. 2007. The Genus Psychotria (Rubiaceae) in the Philippine Archipelago. Botanical Research. Institute of Texas Press, Texas.

Talbot WA, Mariyammal R, Kavimani S. 2013. Anti-inflammatory activity of methanol extract of the whole pant of Psychotria octosulcata. Intl J Pharma Res Rev 2 (11): 1-5.

Tan M, Panghulan G, Uy M, Takayama H. 2014. Chemical Constituents from Psychotria cadigensis and their chemotaxonomic relevance. Am J essent oils nat prod 1 (4): 18-19.

Taylor C. 2016. Rubiacearum americanarum magna hama pars xxxi: more new neotropical species and morphological notes for Psychotria (Psychotrieae). Novon (St Louis) 24 (4): 413-434. DOI: $10.3417 / 2015021$

Tran P, Le V, Do T, Nguyen T, Nguyen P, Nguyen TT, Nguyen TD. 2017. Anti-inflammatory constituents from Psychotria prainii H. Lév. Nat Prod Res 33 (5): 695-700. DOI: 10.1080/14786419.2017.1408095.
Trisurat Y, Shrestha RP, Kjelgren R. 2011. Plant species vulnerability to climate change in Peninsular Thailand. Appl Geogr 31: 1106-1114.

van der Ploeg J, van Weerd M, Masipiqueña A, Persoon G. 2011. Illegal logging in the Northern Sierra Madre Natural Park, the Philippines. Conserv Soc 9 (3): 202-215. DOI: 10.4103/0972-4923.86991.

Virillo CB, Ramos FN, Castro CD. 2007. Floral Biology and breeding system of Psychotria tenuinervis Muell. Arg. (Rubiaceae) in the Atlantic rain forest, SE, Brazil. Acta Bot Bras 21 (4): 879-884

Wahab F, Subramaniam K, Suriyamoorthy S, Subburaj SP. 2012. Phytochemical analysis and antagonistic activity of Ixora macrothyrsa on multidrug-resistant bacteria. Asian Pac J Trop Biomed 2: 1312-1316. DOI: 10.1016/S2221-1691 (12)60407-9.

Wulff AS, Hollingsworth PM, Ahrends A, Jaffre' T, Veillon J-M, L'Huillier L, Fogliani B. 2013. Conservation priorities in a biodiversity hotspot: analysis of narrow endemic plant species in New $\begin{array}{lllll}\text { Caledonia. } & \text { PLoS ONE. } 8 \text { (9): e73371. DOI: }\end{array}$ 10.1371/journal.pone.0073371.

Yang LH, Rudolf VHW. 2010 Phenology, ontogeny and the effects of climate change on the timing of species interactions. Ecol Lett 13: 110. DOI: $10.1111 / \mathrm{j} .1461-0248.2009 .01402 . x$.

Yoga Latha L, Darah I, Jain K, Sasidharan S. 2012. Pharmacological screening of methanolic extract of Ixora species. Asian Pac J Trop Biomed 2: 149-151. DOI: 10.1016\%2FS2221-1691(11)60210-4. 